\title{
Ten years of the Kenya Adolescent Reproductive Health Project: What has happened?
}

\author{
Humphres Evelia \\ Population Council \\ Monica Wanjiru \\ Population Council \\ Francis Obare \\ Population Council \\ Harriet Birungi \\ Population Council
}

Follow this and additional works at: https://knowledgecommons.popcouncil.org/departments_sbsr-rh

Part of the Demography, Population, and Ecology Commons, Family, Life Course, and Society Commons, International Public Health Commons, Medicine and Health Commons, and the Public Health Education and Promotion Commons How does access to this work benefit you? Let us know!

\section{Recommended Citation}

Evelia, Humphres, Monica Wanjiru, Francis Obare, and Harriet Birungi. 2011. "Ten years of the Kenya Adolescent Reproductive Health Project: What has happened?" APHIA II OR Project in Kenya report. Nairobi: Population Council. 


\section{Ten years of the Kenya Adolescent Reproductive Health Project: What has happened?}

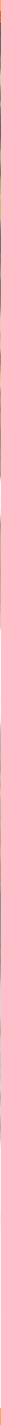




\section{Ten years of the Kenya Adolescent Reproductive Health Project: What has happened?}

APHIA II Operations Research Project/ Population Council Humphres Evelia, Monica Wanjiru, Francis Obare, Harriet Birungi

May 2011 


\section{Contents}

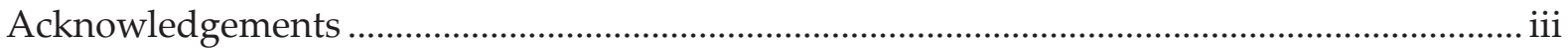

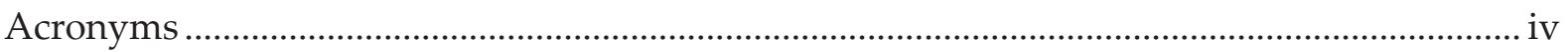

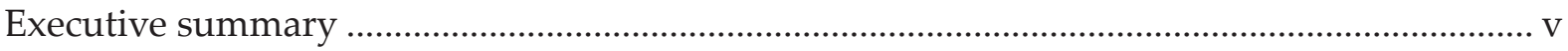

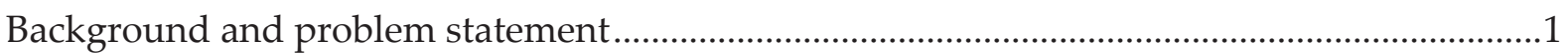

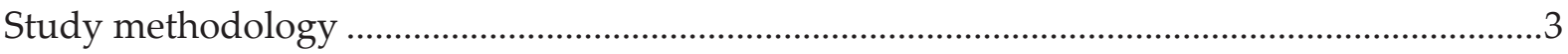

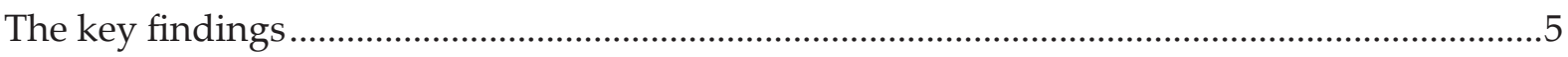

Evidence of sustained effect on adolescents' knowledge and behaviors ................................ 11

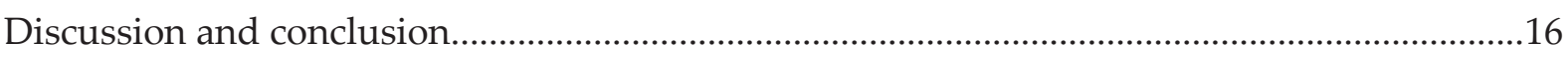

Annex 1: Policy documents and workplans reviewed ...........................................................18

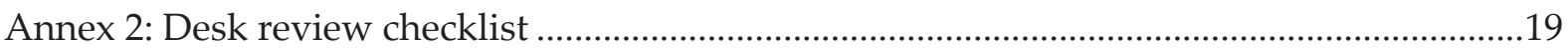

\section{List of tables}

Table 1: Distribution of survey respondents by background characteristics ............................. 3

Table 2: National assessment, in-depth interviews and group discussions conducted ............ 4

Table 3: Proportions of schools implementing ASRH activities ............................................... 8

Table 4: Proportion of adolescents who have ever heard of reproductive

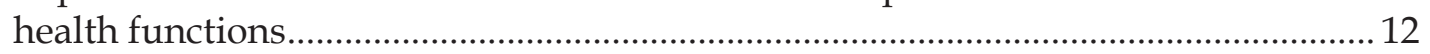

Table 5: Proportions reporting ever heard of specific methods ............................................... 13

Table 6: Summary of findings on selected indicators over the three KARHP studies 


\section{Acknowledgements}

The authors would like to thank the people who facilitated this evaluation, and who participated in the study in one way or another. Specifically, we would like to acknowledge the contribution of staff from the Ministry of Education, Ministry of Public Health and Sanitation, Ministry of Medical Services, Ministry of Gender Children and Social Development, Ministry of Youth Affairs and the APHIA II partners in the seven provinces where the study took place. Their support was critical in guiding the study and the fieldwork.

We would also like to thank the staff who carried out the fieldwork - the research assistants for their dedication during data collection; Denis Khamati for coordinating all data collection activities; and Cornelius Mutangili for supporting the desk review of documents. We would also like to thank staff from the Population Council who supported this study: Ian Askew, for his invaluable guidance and advice throughout the study process; Winnie Osulah for coordinating fieldwork logistics; Eric Oweya for overseeing data entry and analysis; and Janet Munyasya for supporting preparation of the final edition of report.

Finally, we thank the respondents who took part in the study - ministry officials, teachers and young people who participated in the survey for their willingness and cooperation and to USAID through APHIA II OR/ Population Council for funding this study.

This publication has been made possible with the generous support of the American people through USAID/Kenya, under the APHIA II Operations Research Project, a cooperative agreement No. 623-A-00-09-00001-00 between the Kenya Mission and the Population Council. The opinions expressed herein are those of the authors and do not necessarily reflect the views of USAID.

Suggested Citation: Evelia H., Wanjiru M., Obare F., Birungi H., (2011) Ten years of the Kenya Adolescent Reproductive Health Project: What has happened? APHIA II OR Project in Kenya/ Population Council: Nairobi, Kenya

(C) 2011, The Population Council, One Dag Hammarskjold Plaza New York, New York, 10017, www.popcouncil.org. The document may be freely reviewed, abstracted, reproduced or translated, in part or in whole, but not for sale nor use in conjunction with commercial purposes. 


\section{Acronyms}

$\begin{array}{ll}\text { AEO } & \text { Area Education Officer } \\ \text { APHIA } & \text { AIDS, Population and Health Integrated Assistance Program } \\ \text { ASRH } & \text { Adolescent Sexual and Reproductive Health } \\ \text { AOP } & \text { Annual Operations Plan } \\ \text { BOG } & \text { Board of Governors } \\ \text { CBOs } & \text { Community Based Organizations } \\ \text { CDF } & \text { Constituency Development Fund } \\ \text { DEO } & \text { District Education Officer } \\ \text { DHS } & \text { Demographic and Health Survey } \\ \text { DO } & \text { District Officer } \\ \text { DPHN } & \text { District Public Health Nurse } \\ \text { DSDO } & \text { District Social Development Officer } \\ \text { FGD } & \text { Focus Group Discussion } \\ \text { FGM } & \text { Female Genital Mutilation } \\ \text { G\&C } & \text { Guidance and Counseling } \\ \text { GoK } & \text { Government of Kenya } \\ \text { GTZ } & \text { German Technical Co-operation } \\ \text { HIV/AIDS } & \text { Human Immunodeficiency Virus/Acquired Immunodeficiency } \\ & \text { Syndrome } \\ \text { IEC } & \text { Information, Education and Communication } \\ \text { KARHP } & \text { Kenya Adolescent Reproductive Health Program } \\ \text { KNBS } & \text { Kenya National Bureau of Statistics } \\ \text { MoE } & \text { Ministry of Education } \\ \text { MOEST } & \text { Ministry of Education, Science and Technology } \\ \text { MGSCSS } & \text { Ministry of Gender, Sports, Culture and Social Services } \\ \text { MoH } & \text { Ministry of Health } \\ \text { MOYAS } & \text { Ministry of State for Youth Affairs and Sports } \\ \text { MDGs } & \text { Millennium Development Goals } \\ \text { MYWO } & \text { Maendeleo Ya Wanawake Organization } \\ \text { NACC } & \text { National AIDS Control Council } \\ \text { NASCOP } & \text { National AIDS and Sexually Transmitted Disease Control Programme } \\ \text { NCAPD } & \text { National Coordinating Agency for Population and Development } \\ \text { NGO } & \text { Non Governmental Organization } \\ \text { OR } & \text { Operations Research } \\ \text { PATH } & \text { Programme for Appropriate Technology in Health } \\ \text { PHTs } & \text { Public Health Technicians } \\ \text { SDAs } & \text { Social Development Assistants } \\ \text { SMC } & \text { School Management Committees } \\ \text { STI } & \text { Sexually Transmitted Infections } \\ \text { TAC } & \text { Teacher Advisory Centre } \\ \text { UNDP } & \text { United Nations Development Programme } \\ \text { UNFPA } & \text { United Nations Population Fund } \\ \text { UNICEF } & \text { United Nations Children's Fund } \\ \text { USAID } & \text { United States Agency for International Development } \\ & \end{array}$




\section{Executive summary}

In 1999, the Kenya Adolescent Reproductive Health Project (KARHP) was introduced as a pilot research project in two districts in Western Province. KARHP was designed in collaboration with three government ministries and comprised activities implemented in schools, communities and health facilities. When the project was evaluated in 2004, it was found to be effective in achieving positive reproductive health outcomes for young people. Over the next ten years, the project was replicated and scaled up to cover seven provinces in the country. This evaluation study sought to find out whether the ASRH/HIV/AIDS activities and desired reproductive health outcomes have been sustained. The evaluation had three main objectives: i) determine the extent to which activities of KARHP have continued at national, provincial, district levels; ii) determine whether desired sexual and reproductive health outcomes (knowledge, behavior and practices) have been sustained among in and out of school adolescents over time; iii) identify challenges experienced by various partners in sustaining the model.

A range of research methods were used, including review of policies, guidelines and annual operations plans drawn by various ministries; a knowledge, attitude and practices survey among 10-19 year olds; a school assessment to establish the status of KARHP activities; and qualitative assessment to establish the status of KARHP activities implemented by the three ministries (Education, Health and Gender and Social Services).

The findings show that policy documents and guidelines developed during this period have increasingly given priority to ASRH/HIV/AIDS issues. For instance, the Ministry of Youth Affairs and Sports (MOYAS) has included implementation of ASRH/HIV/AIDS activities in its staff performance contracts. The government has also allocated funding to support the rollout of ASRH activities. However, the study found weaknesses in the monitoring and evaluation of all ASRH activities implemented by the three ministries.

The school assessment found that life-skills education was widely offered in schools $92 \%$ of schools in the sample said they taught life skills supported by peer education, or had integrated ASRH themes into extracurricular activities. Most schools also had health clubs and offered referrals for health services to local health facilities. The study also found that in most schools, guidance and counseling teachers conducted the life-skills sessions, although other teachers had integrated the topic into other subjects as appropriate. It was established that the three ministries had included ASRH activities in their work-plans and strategies, although they faced challenges, including inadequate funding, limited staff and weak monitoring of activities.

The results show that reproductive health knowledge and behavior had improved among the adolescents. A significant increase was found in the proportions of adolescents who have delayed sexual debut. The study also found significant improvement in the proportion of adolescents who reported safer sexual practices at first sex in comparison with an earlier survey of the same project in 2004 . Condoms 
remain the method of choice for the sexually active adolescents interviewed. However, it was found that most of the adolescents had poor knowledge of correct condom use - a significant proportion of adolescents could not state the correct steps in using a condom, perhaps due to less emphasis of these steps in condom messaging and promotions.

Although the survey suggests that the efforts to sustain KARHP/ ASRH activities may have desirable behavioral outcomes among adolescents, there is need to strengthen these activities to increase their effect. It is also necessary to streamline coordination of ASRH activities by the different partners in order to consolidate efforts, strengthen funding, and monitoring and evaluation and activities. 


\section{Background and problem statement}

The Kenya Adolescent Reproductive Health Programme (KARHP) ${ }^{1}$ was initiated in 1999 by Population Council and PATH as an operations research study to test the feasibility of implementing an adolescent reproductive health program within the public sector in two districts of Western Province, Kenya (see Box 1). An evaluation of the intervention in 2003 showed that it was indeed feasible and effective to implement RH programs within the public sector. Between 2003 and 2005, selected activities were expanded and scaled up by the three ministries that implemented the pilot project (Ministry of Health, Ministry of Education, Science and Technology, and the Ministry of Gender, Sports, Culture and Social Sciences ${ }^{2}$ ). The ministries were assisted in integrating the selected activities within their work plans, monitoring and supervision systems and budgets. Tools and materials that had been used in the Operations Research study were revised and adapted for use in the expanded programme, and inter-ministry coordination committees were set up.

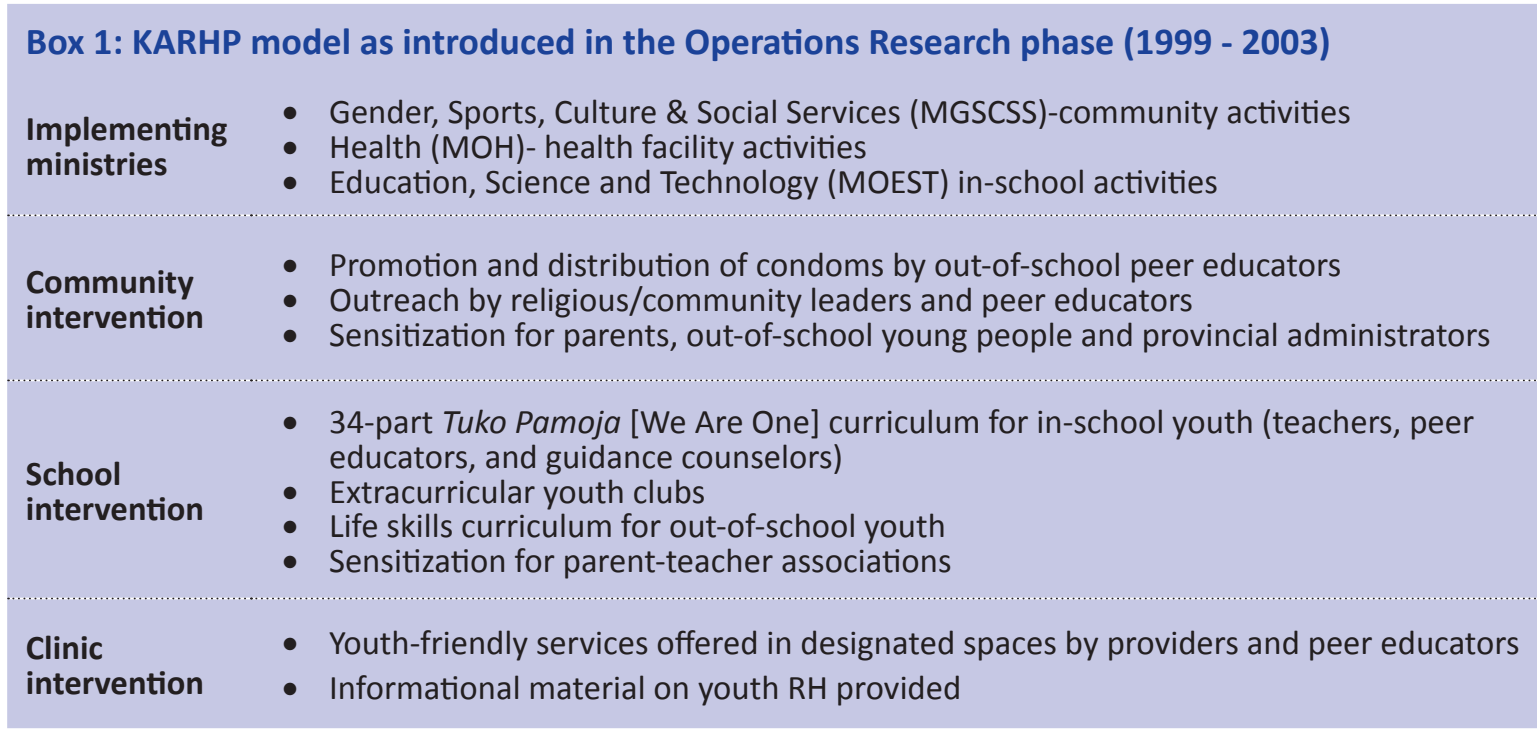

From June 2005 to June 2006, the three ministries scaled up specific KARHP activities to all eight districts of Western Province. This was followed by a staged nationwide replication of the model from 2006 to 2008 covering two provinces each year. With assistance from Population Council and with materials used in the pilot phase, the ministries rolled out KARHP activities in six provinces; Nyanza and Eastern between June 2006 to May 2007; Nairobi and Central in June 2007 to May 2008; Coast in 2008 and in Rift Valley in 2008. APHIA II Rift Valley introduced activities in Rift Valley

\footnotetext{
${ }^{1}$ Askew Ian, Jane Chege, Carolyne Njue, and Samson Radeny. 2004 “A multisectoral approach to providing reproductive health information and services to young people in Western Kenya: The Kenya Adolescent Reproductive Health Project," FRONTIERS FINAL REPORT Washington DC: Population Council

${ }^{2}$ Since the initiation of KARHP the Ministry of Gender, Culture and Social Services has been split into two ministries- Ministry of Gender, Children and Social Development and Ministry of Youth Affairs and Sports.
} 
Province in $2008^{3}$. In each province, the program was first introduced in two pilot districts in the first year, followed by expansion to the rest of the districts in the second year with assistance from APHIA $\mathrm{II}^{4}$ partners in the respective provinces.

In February 2010, when the Ministry of Health published the first-ever compendium of best practices in reproductive health in Kenya ${ }^{5}$, the institutionalization of KARHP was identified as one of the eight best practices in the country. A program was considered a best practice if it was evidence-based and had demonstrated impact; if it could be replicated; was cost-effective and sustainable (i.e., integrated within Kenya's Ministry of Health systems); and had led to increased service utilization.

Feedback from ministries involved in the implementation of the programme over the last ten years suggests that KARHP activities have been adopted in work plans, budgets and policies. However, no systematic study had been undertaken to assess whether KARHP activities have indeed been sustained at national, provincial and district levels.

Systematic assessment of the sustainability of KARHP is therefore critical to demonstrate that activities have continued over time and space. Such evidence can improve decision making on institutionalization of a pilot project, and provide an opportunity to identify what works. This study examines the status and sustainability of KARHP over time in order to draw critical lessons in scaling up this pilot intervention. Specifically, the study aimed to:

1) Determine the extent to which KARHP activities have continued at national, provincial, district levels;

2) Determine whether desired sexual and reproductive health outcomes (knowledge, behavior and practices) have been sustained among in- and outof school adolescents over time; and

3) Identify challenges experienced by various partners in sustaining the model.

The evaluation contributes to the USAID/ Kenya Five-Year Implementation Plan for the Health Sector (2010-2015) IR 4.3 and the APHIAplus strategy. It further contributes to the planned review of the Kenya Adolescent Reproductive Health Policy by the National Coordinating Agency for Population and Development (NCAPD) and DRH.

\footnotetext{
${ }^{3}$ Askew Ian and Evelia Humphres. 2007. Mainstreaming and Scaling Up the Kenya Adolescent Reproductive Health Project. Population Council Frontiers in Reproductive Health Program.

${ }^{4}$ APHIA II refers to AIDS, Population and Health Integrated Assistance program, Phase II. This is a program funded by the United States Agency for International Development (USAID) with the aim of improving health outcomes in Kenya.

${ }^{5}$ Division of Reproductive Health, Government of Kenya 2009: Best Practices in Reproductive Health in Kenya. Nairobi
} 


\section{Study methodology}

This was an exploratory study carried out between December 2009 and March 2010. The study was approved by the National Council for Science and Technology and used a range of methods, including desk review, a survey among adolescents, school and national assessments.

\section{Desk review}

A total of 29 documents (Annex 1), including ministry policy guidelines, Annual Operations Plans (AOPs) and work plans for APHIA II partners were reviewed retrospectively to the time KARHP was initiated in 1999, to identify if ASRH/ HIV/AIDS activities had been integrated into policy and program frameworks. The review was conducted using a checklist (Annex 2) to examine, among other indicators, resource allocation as well as monitoring and evaluation mechanisms.

\section{Knowledge attitude and practice survey among adolescents}

A knowledge, attitude and practice (KAP) household survey was conducted in the original KARHP pilot divisions of Sabatia and Nambale in Western Kenya to determine whether desired sexual and reproductive health outcomes had been sustained over the last ten years. The KAP survey examined adolescents' knowledge about contraceptive methods and sexually transmitted infections (STIs); attitudes towards premarital sex and childbearing; and sexual practices including sexual debut.

The survey followed a sampling strategy and design similar to that used in the 2003 study. The study targeted in- and out-of-school adolescents aged 10-14 years using a revised version of the 2003 questionnaire. A total of 2,406 adolescents aged 10-19 years (1,307 females and 1,099 males) were interviewed in the Sabatia and Nambale divisions. Survey results were then compared to those from the 2003 study to decipher health behaviors over time. Only differences that were statistically significant between the OR studies and the 2010 assessment at the level of 0.05 and 0.01 were considered indicative of a probable change. Table 1 describes the general characteristics of study respondents in the ten year evaluation study.

Table 1: Distribution of survey respondents by background characteristics

\begin{tabular}{|l|l|l|l|l|l|}
\hline \multirow{2}{*}{\multicolumn{2}{|c|}{ Characteristics }} & \multicolumn{2}{c|}{ Males } & \multicolumn{2}{c|}{ Females } \\
\cline { 3 - 6 } & Nambale & 549 & 50 & 652 & 50 \\
\multirow{2}{*}{ Site } & Sabatia & 550 & 50 & 655 & 50 \\
\hline \multirow{2}{*}{ Age } & $10-14$ & 598 & 54 & 678 & 52 \\
& $15-19$ & 501 & 46 & 629 & 48 \\
\hline Ever attended school & & 1094 & 100 & 1302 & 100 \\
\hline Current/ highest level of & Primary & 859 & 79 & 1008 & 77 \\
schooling completed & Secondary & 133 & 21 & 289 & 22 \\
\hline Ever worked for pay & & 308 & 28 & 173 & 13 \\
\hline \multirow{2}{*}{ Marital status } & Single & 1097 & 100 & 1271 & 97 \\
& Married & 1 & 0 & 34 & 3 \\
\hline
\end{tabular}




\section{Assessment of KARHP activities in schools}

The purpose of the school assessment was to examine the status and coverage of in-school KARHP activities. A total of 420 primary and secondary schools were randomly selected from a list of 17,800 schools obtained from the Ministry of Education, from the seven provinces where the KARHP model has been implemented. Of the sampled schools, data was only collected from 340 schools $^{6}$. The schools comprised public primary schools (39\%), public secondary schools (42\%), private primary schools (12\%) and private secondary schools (7\%). At the schools, the Guidance and Counselling (G\&C) teachers (91\%) or school heads/ principals (9\%) were interviewed using a simple questionnaire that focused on the following issues:
a. Existence of and support for KARHP activities;
b. Integration of KARHP activities into regular schooling schedules; and
c. Availability of KARHP and other ASRH materials in schools.

\section{Assessment of KARHP activities implemented nationally}

The assessment involved in-depth interviews and group discussions with officials from national, provincial and district levels to determine the extent to which KARHP activities have continued and to identify the factors that may have facilitated or inhibited sustainability of the model. Table 2 summarizes the number of in-depth interviews and group discussions conducted.

Table 2: National assessment, in-depth interviews and group discussions conducted

\begin{tabular}{|c|c|}
\hline Target & Location \\
\hline $\begin{array}{l}\text { Contact officials from four ministry } \\
\text { head offices }\end{array}$ & 4 in-depth interviews with national officials from the four ministries \\
\hline $\begin{array}{l}\text { Ministry officials at provincial level } \\
\text { - Director of Education } \\
\text { - Youth Officer } \\
\text { - Medical Officer } \\
\text { - Director of Social Services and } \\
\text { Children Affairs } \\
\text { - Public health Technician }\end{array}$ & $\begin{array}{l}32 \text { in-depth interviews with ministry } \\
\text { - Nairobi Province } \\
\text { - Central Province } \\
\text { - Eastern Province* } \\
\text { - Nyanza Province } \\
\text { - Coast Province } \\
\text { - Western Province } \\
\text { - Rift valley Province* } \\
\text { *APHIA II Partners were also interviewed in Eastern and Rift Valley }\end{array}$ \\
\hline $\begin{array}{l}\text { Members of District Inter-Ministry } \\
\text { Committees (DIMCs) from two } \\
\text { pilot districts per province } \\
\text { - District Education Officer } \\
\text { - District Social Development } \\
\text { Officers/ Youth Officers } \\
\text { - District Public Health Officer } \\
\text { - District Medical Officer for } \\
\text { Health }\end{array}$ & $\begin{array}{l}\text { A total of } 7 \text { group discussions with DIMCs members in the following } \\
\text { provinces: } \\
\text { - Nairobi Province } \\
\text { - Central Province } \\
\text { - Eastern Province } \\
\text { - Nyanza Province } \\
\text { - Western Province }\end{array}$ \\
\hline
\end{tabular}

\footnotetext{
${ }^{6}$ Not all schools included in the sample were visited, because in some cases the head teacher was not available to give permission for interviews with teachers; in others, the G\&C teachers were not available. In addition, some schools did not honor appointments when research assistants visited.
} 


\section{Key findings}

\section{Evidence of continuation of KARHP activities}

At the inception of KARHP in 1999, there was little recognition and support for ASRH including HIV/AIDS in government policies, work plans and activities. There were no systematic education programmes on life-skills for in- and out-of-school adolescents and provision of adolescent reproductive health services was shrouded in controversy, with fears that it would lead to promiscuity ${ }^{7}$. Our results show that this has changed. ASRH issues have achieved visibility in national plans and policies.

This assessment found that at least 16 documents on adolescent reproductive health and HIV have been developed by the government over the last ten years (Annex 1). This includes policy documents and sector/ service strategy plans. In general, the documents review showed that ASRH issues have been well articulated in relevant policy documents and ministry work-plans. Specific activities have been identified, implementation approaches suggested and in some cases, monitoring and budgetary components included.

\section{Continuation of activities by the Ministry of Education}

The first policy on HIV in the Education Sector was developed in 2004 at a time when KARHP OR activities were being adapted and scaled up by the government and its partners. Since then, four other policy documents have been formulated that further institutionalize SRH life-skills training and HIV prevention education within the Ministry activities:
i. (2005) Sessional Paper No 1 - Education
ii. (2007) Gender Policy in Education
iii. (2008) Draft Guidance and Counseling policy
iv. (2009) MOE HIV/AIDS Life-skills Training Manual

The Education Sector Policy on HIV stipulated that pre-service teacher training should equip teachers with skills to "build skills and positive attitudes" for HIV prevention among pupils. It also stipulates that life-skills training should be included in all school activities. In 2005, the Ministry launched the five-year Kenya Education Sector Support Program Strategic Plan (2005-2010), which outlines several activities that should be put in place to implement the policy on HIV/AIDS within schools. These include training teachers to teach life-skills education, using peer education, setting up school health clubs and strengthening guidance and counseling. The document also includes financial commitments by the Ministry to support these activities.

\footnotetext{
${ }^{7}$ Askew Ian, Chege Jane, Njue Carolyne, Radeny Samson. 2004. A multi-sectoral approach to providing reproductive health information and services to young people in Western Kenya. The Kenya adolescent reproductive health project. FRONTIERS Final Report
} 
During this period, the Guidance and Counseling Unit within the Ministry had started to gain visibility and was allocated a budget by the Ministry to strengthen it and support implementation of ASRH activities within schools. In 2006, with substantive input from PATH, Population Council and other stakeholders, the Ministry of Education began developing a National Guidance and Counseling policy to strengthen guidance and counseling and teaching life skills education in schools.

To further support the integration of life-skills in schools, a ministerial circular was issued in 2007, which required all primary and secondary schools in the country to provide life skills education as a non-examinable subject and to include it in the school timetable once a week:

"After consultation with stakeholders, it has been agreed that life skills be introduced as a standalone subject in primary and secondary education. In view of this, all schools are hereby advised to timetable and teach Life Skills as a non-examinable subject once a week..." [Ministry of Education, Directorate of Quality Assurance and Standard Ref N0. QAS/A/2/1A/75 circular on teaching life skills in primary and secondary schools, dated December $18^{\text {th }}$ 2007]

In 2009, the Kenya Institute of Education (KIE) launched a life-skills training manual for in-school teaching, which covered a wide range of adolescent sexual and reproductive health issues. The manual's content is very similar to the KARHP curriculum, and indeed, the Guidance and Counseling Unit has recommended the comprehensive "Tuko Pamoja" curriculum as a reference guide for teachers implementing the KIE curriculum.

During the KARHP expansion phase (2006-2008), the Ministry of Education also directly supported the expansion of activities within schools in four provinces (Coast, Eastern, Western and Nyanza). For instance, in 2006 in Western Province, the Provincial Education Board approved funding to expand KARHP to two thirds ${ }^{8}$ of schools in the province that had not been covered by KARHP. ${ }^{9}$ Similar support was given by district educational boards in Eastern province (Meru Central District) and Nyanza provinces (Kisumu District) for schools not covered by KARHP funding.

In April 2007, the MOE allocated Kshs 2.1 million to roll-out the program to 600 schools in Nyanza and Eastern provinces. In total, 12 districts benefited from this expansion including Nyamira, Homa Bay, Kuria, Suba, Siaya and Bondo in Nyanza Province and Tharaka, Meru South, Meru North, Kitui, Mwingi and Makueni in Eastern Province. 264 Ministry staff (teachers and MOE officials) were trained

\footnotetext{
${ }^{8}$ Experience by Centre for British Teachers (CfBT) and KARHP in Western Province demonstrated that training staff and parent representatives from one third of the primary and secondary schools in a district could effectively ensure that sufficient capacity to provide school-based HIV and RH information is built within the Ministry at the district level. The Ministry of Education, Science and Technology (MOEST) can then take responsibility to ensure that this capacity is used to introduce KARHP into the remaining two-thirds of schools.

${ }^{9}$ Askew Ian and Evelia Humphres. 2007. Mainstreaming and scaling up the Kenya Adolescent Reproductive Health Project. Population Council. Frontiers in Reproductive Health Program.
} 
in Nyanza Province and 238 in Eastern Province. Population Council and PATH provided materials (Tuko Pamoja manual) and technical assistance in planning and facilitating expansion. In April 2008, the MOE approved a further KShs 1.5 million to expand KARHP to four districts in Coast Province and two districts in Eastern Province. A total of 1200 schools were covered during this expansion and Population Council provided technical support. ${ }^{10}$

\section{KARHP continuation in schools}

Results of the field assessments support the findings of the document review, and show that indeed, the activities introduced under KARHP have been adapted by the MOE. The assessment found that $92 \%$ of schools visited offer teaching of life-skills, peer education, integration of ASRH in extracurricular activities, health clubs and debat clubs, and referrals for SRH and other health services at health facilities.

Schools in the study were asked if they were implementing any adolescent life-skills, sexual and reproductive health and HIV/AIDS education. Over $92 \%$ of all schools surveyed reported implementing life-skills training. The study found that although the activities were mainly run by the G\&C teachers $(84 \%)$ in schools, other teachers $(52 \%)$ had also taken up the responsibility and were integrating it in other subjects appropriately. About $16 \%$ of schools reported that head teachers participated in running these activities.

Findings show that $96 \%$ of the schools surveyed had a guidance and counseling department/ unit, with at least two teachers (93\%), indicating that the Ministry's efforts to strengthen guidance and counseling have been successful. Over $61 \%$ of schools reported that they had a question box into which students can drop in questions to issues raised during life-skills sessions. The study found that slightly over half (56\%) of the schools had a life-skills curriculum. Over twenty different types of curricula/ educational manuals from different stakeholders were found to be in use in schools, including KIE's Life skills syllabus "Tuko Pamoja" by KARHP and texts from the Centre for British Teachers' (CfBT) Action for Better Health programme. Most of the schools ( $80 \%)$ used the curricula as reference material while only $14 \%$ used it as a teaching aid.

Over two thirds of all schools (70\%) had life-skills sessions slotted into the school timetable, and about $93 \%$ of these schools had at least one lesson per week. In the primary schools, life-skills were taught mostly to the upper classes from Class Four. Seventy-eight percent of the schools reported that they integrated life-skills/SRH/ HIV/AIDS messages into extra-curricular activities including sports, music and drama, art, club activities, school open days and exhibition days.

\footnotetext{
${ }^{10}$ Evelia et. al. 2008 From pilot to program: Scaling up the Kenya Adolescent Reproductive Health Project Frontiers in Reproductive Health, Population Council.
} 
Over two thirds of schools (72\%) reported that they had peer educators. About 77\% of the schools with peer educators had trained them with support from different agencies working in the regions including APHIA II partners. In $25 \%$ of schools, the peer educators used manuals and other materials supplied by partners. The following table summarizes the range of ASRH activities implemented in schools.

Table 3: Proportions of schools implementing ASRH activities

\begin{tabular}{|l|c|c|}
\hline Activity & $\mathbf{N = 3 4 0}$ & $\%$ \\
\hline Implementing any life skills/ ASRH activities & 314 & $92 \%$ \\
\hline With G\&C department/ teacher & 325 & $96 \%$ \\
\hline With any life skills curriculum & 188 & $56 \%$ \\
\hline With a question box & 206 & $61 \%$ \\
\hline With peer educators & 243 & $72 \%$ \\
\hline With KARHP/ Health clubs & 131 & $39 \%$ \\
\hline With life skill on timetable & 236 & $70 \%$ \\
\hline Integrating ASRH/HIV in extracurricular activities & 265 & $78 \%$ \\
\hline With RH/HIV/AIDS IEC materials & 216 & $64 \%$ \\
\hline Offering referral for health services & 249 & $74 \%$ \\
\hline $\begin{array}{l}\text { With KARHP “Tuko Pamoja" curriculum (out of 188 } \\
\text { schools with any life skills curriculum) }\end{array}$ & 65 & $37 \%$ \\
\hline
\end{tabular}

The school assessment findings were supported by feedback received in interviews with Ministry of Education officials at the provincial level, which show that strategies have been put in place to ensure ASRH activities continue even when teachers leave:

"We have structures and strategies [for continuity of ASRH activities] that is why for example if you as the head of guidance and counseling are promoted, to maybe, the head teacher, somebody else is promoted to take up that position. So in any school that we have HOD [Head of Department] guidance and counseling, there is no one day that office is done away with. Once established it just stays. (In-depth interview, Provincial Officer, Ministry of Education Western Province)

Those interviewed expressed confidence that teaching life skills and having ASRH activities in schools had contributed to improve confidence levels in students, reduced incidences of pregnancy, increased goal setting and improved academic performance:

"Among the members, I called the teachers and they told me the performance has gone up and there are fewer pregnancies and there is behavior change" (FGD participant Rift Valley Province)

"...in one of our districts in Butere during our meeting they were able to tell us that before they initiated [KARHP] they had high school drop outs because of early pregnancies. When these activities took root, it cut down to even less than five.... It helps have higher school retention and pupils pursue their education fully" (In-depth interview, Provincial Officer, Ministry of Education Western Province) 


\section{Continuation of activities by MGCSD and MOYAS}

Among the roles of the Ministry of Gender, Children and Social Development (MGCSD) is providing leadership and policy direction in addressing the needs of young people out of school, and in vocational training institutes. The Ministry of Youth Affairs and Sports (MOYAS) was created in 2005, to further advance government efforts to meet the unique needs of a large youthful population. During the 10-year period of KARHP implementation, the two ministries developed several policy and strategic documents on ASRH/HIVAIDS, four of which were reviewed under this assessment. These include:

i. (2006) National Youth Policy

ii. (2007) National Plan of Action for the Health Component of the National Youth Policy

iii. (2008) Ministry of Youth Affairs National policy for youth training

iv. (2009) MOYAS Training Manual - Trainees Handbook

The development of the National Youth Policy borrowed heavily from the Ministry's experience in the implementation of KARHP. The health component of the policy identifies priority areas to be addressed by the Ministry including:

i. Establishing guidance and counseling units managed by the youth in all schools and other learning institutions under the Ministry;

ii. Promoting and enhancing affordable or free counseling programmes on health-related issues, especially peer-to-peer counseling in faith-based institutions;

iii. Encouraging parents to take an active role in teaching and counseling their children on responsible sexual behavior;

iv. Improving access to voluntary counseling and testing (VCT) services for all youth.

To ensure that the activities were implemented accordingly, staff performance contracts included youth health and social development priorities. In 2009, the Ministry of Youth Affairs and Sports developed a training manual and a trainees handbook for life-skills training, and both cite KARHP's 'Tuko Pamoja' as a key resource. The national assessments found that that Ministry staff in the provinces have continued to use the community-centered approach to address issues affecting youth including SRH and HIV/AIDS:

"In our Ministry [MGCSD], what we usually do once we go to the baraza [or] youth meeting, we talk about drugs, we talk on something about KARHP, on issues affecting the community directly we touch on drugs, HIV and related issues" (FGD participant, Eastern Province)

"For us, we have an action plan under the ministry that basically targets groups within the youth [including] youth with special needs ... we also have youth with teenage pregnancies, those vulnerable by the fact that they are from the street or from the slums or informal sectors and then the action plan is structured in a way that what we are doing as a Ministry now forms part of the larger health intervention". (MOYAS-FGD participant, Nairobi Province) 


\section{Activities by the Ministry of Health}

The Ministry of Health recognizes youth as a priority group for health interventions in its policy documents and expressly recommends specific strategies to reach young people with information and services. In 2003, the Ministry of Health and the then National Council for Population and Development (NCPD) developed the Kenya Adolescent Reproductive Health and Development (KARHD) policy and the accompanying Action Plan (2005), which outline strategies to reach adolescents with information and services. The two documents were heavily informed by the KARHP experience and recommend strategies that had been introduced under the project. These include: provision of youth friendly services (YFS) through static and outreach services including, workplaces, community/ outreach events and school programs; training service providers and peer educators to offer lifeskills training for youth and integration of ASRH with other programs including livelihood programs. The Plan of Action also identifies ASRH indicators for use in the monitoring and evaluation plan.

Since 2006, the Ministry has consistently prioritized health needs of young people in successive annual operational plans (AOPs). In addition, the 2007 National Reproductive Health Policy recognizes health needs of adolescents and identifies strategies for responding to them. The policy clearly recommends a multi-sectoral approach to increase access to information and services for adolescents. The national $\mathrm{RH}$ curriculum for service providers has included a lot of content similar to that in the KARHP curriculum for service providers and cites "Tuko Pamoja" curriculum as a key resource. The creation of the Division of Child and Adolescent Health is also seen as an effort to create more visibility for ASRH issues within the Ministry.

In-depth interviews with Ministry officials in the provinces found that the Ministry of Health has continued to promote youth friendly $\mathrm{RH}$ services, including the provision of contraception for sexually active adolescents, HIV prevention information and VCT services, and PMTCT services for pregnant adolescents. Through the community-based Public Health Technicians, the Ministry encourages referrals for services for young people in the community:

In the Public Health Ministry, the Public Health Officers when they meet with youth groups, they discuss topics on teenage pregnancies, abortion, HIVIAIDS and also in our health facilities. We encourage the young people to come here even if they don't have a formal youth clinic, community health workers also have report centers where give advice to the youths. (FGD participant, Eastern Province)

However, the assessment found that monitoring of activities needs to be strengthened. For instance, there was no indication found that measurement of gains made in successive AOPs had taken place. In addition, since the development of the Adolescent Sexual and Reproductive Health and Development policy (2003), no measurement of impact has been undertaken. 
Cross-cutting issues supporting the continuity of ASRH activities in the provinces

Findings from the desk review of ministry work plans showed that the government has made efforts to provide funding for ASRH/HIV/AIDS activities, through allocations to specific ministries. In the provinces and districts, the national assessments found that Constituency Development Funds have been used to support ASRH/HIV/AIDS activities, especially setting up infrastructure, including health facilities and youth centers. The ministries also leverage for resources from partners (example USAID, PEPFAR, CDC, UN agencies, DFID, GTZ, European Union, and local banks) to support activities, including training staff and the implementation of programs.

The assessment found that inter-ministry collaboration, a key feature under KARHP, had weakened and the coordination committees that led the implementation of ASRH activities no longer met. Discussions with local staff from the three ministries found that the committees may have been undermined by inadequate funding and lack of coordination:

I have heard of the Inter-ministerial Committee which consists of the Ministry of Health, Education, Gender and Culture and Social Services. There was a meeting held last year-2008 where departments were been informed that APHIA II will take over operations from the Population Council, a Chairperson was selected and meetings were to be held. I am not sure if there has been any meeting. (FGD participant, Eastern Province)

In some cases, the inter-ministry coordination was integrated into existing interdepartmental committees coordinated by the District Commissioner or the District Development Officers (DDO):

"...the DDO district development officer is the one in charge of organizing the committee. Different ministries meet and look through those issues together and what we are implementing we talk and somehow we come up with a strategy. (FGD participant, Rift Valley Province)

\section{Evidence of sustained effect on adolescents' knowledge and behaviors}

According to the 2008-2009 KDHS, sexual initiation is early in Kenya - 11\% of the women and $22 \%$ of the men aged $15-19$ years surveyed nationally had sex by 15 years of age. In Western Province, 8.7\% of the women had sex by 15 years and $48 \%$ by 18 years; among males, $27.3 \%$ had sex by 15 and $69.2 \%$ by age of 18 years. The goal of the KARHP interventions had been to provide adolescents with information on sexual and reproductive health in order to delay sexual initiation and increase safer sex practices among those already sexually active. This evaluation sought to establish whether ASRH knowledge and behaviors had changed over time. In general, this study found that the activities implemented in the ten-year period of KARHP have had a positive effect on knowledge and sexual behavior of young people in the study sites. The following section summarizes these findings. 


\section{Effect on adolescents' knowledge and awareness of $R H$ issues}

Knowledge of RH issues: The findings show that awareness of common RH issues, such as menstruation, dating, sexual intercourse and pregnancy, has been sustained over time. Knowledge was higher among older (15-19 year olds) adolescents as compared to younger adolescents, and an improvement was observed, compared to the 2004 endline evaluation. This may be attributed to continued provision of reproductive health information through schools.

Table 4: Proportion of adolescents who have ever heard of reproductive health functions

\begin{tabular}{|c|c|c|c|c|c|}
\hline & 1999 Baseline & 2004 End line & 2010 Assessment & 1999 vs 2010 & 2004 vs 2010 \\
\hline Boys 10-14 & $N=369$ & $\mathrm{~N}=387$ & $N=598$ & $N=387$ & $N=598$ \\
\hline How body works & $41 \%$ & $43 \%$ & $47 \%$ & ns & ns \\
\hline Menstruation & $37 \%$ & $45 \%$ & $39 \%$ & ns & ns \\
\hline Dating & $38 \%$ & $52 \%$ & $62 \%$ & $* *$ & $* *$ \\
\hline Sexual intercourse & $63 \%$ & $75 \%$ & $84 \%$ & $* *$ & $* *$ \\
\hline Boys 15-19 & $\mathrm{N}=\mathbf{2 7 5}$ & $\mathrm{N}=317$ & $\mathrm{~N}=501$ & $\mathrm{~N}=317$ & $\mathrm{~N}=501$ \\
\hline How body works & $76 \%$ & $74 \%$ & $88 \%$ & $* *$ & $* *$ \\
\hline Menstruation & $86 \%$ & $85 \%$ & $95 \%$ & $* *$ & $* *$ \\
\hline Dating & $72 \%$ & $80 \%$ & $94 \%$ & $* *$ & $* *$ \\
\hline Sexual intercourse & $91 \%$ & $97 \%$ & $98 \%$ & $* *$ & ns \\
\hline Girls $10-14$ yrs & $N=939$ & $N=940$ & $N=678$ & $N=940$ & $N=678$ \\
\hline How body works & $39 \%$ & $49 \%$ & $49 \%$ & $* *$ & Ns \\
\hline Menstruation & $50 \%$ & $68 \%$ & $60 \%$ & $* *$ & $* *$ \\
\hline Dating & $31 \%$ & $47 \%$ & $67 \%$ & $* *$ & $* *$ \\
\hline Sexual intercourse & $54 \%$ & 75 & $83 \%$ & $* *$ & $* *$ \\
\hline Girls $15-19$ yrs & $\mathrm{N}=815$ & $N=874$ & $\mathrm{~N}=629$ & $N=874$ & $N=629$ \\
\hline How body works & $72 \%$ & $75 \%$ & $87 \%$ & $* *$ & $* *$ \\
\hline Menstruation & $94 \%$ & $96 \%$ & $99 \%$ & $* *$ & $* *$ \\
\hline Dating & $73 \%$ & $78 \%$ & $93 \%$ & $* *$ & $* *$ \\
\hline Sexual intercourse & $91 \%$ & $95 \%$ & $99 \%$ & $* *$ & $* *$ \\
\hline
\end{tabular}

${ }^{*} P<0.05 ;{ }^{* *} p<0.01 ; n s-$ Not statistically significant

Knowledge of contraception: The ten-year evaluation study found that nearly half of the boys $(48 \%)$ and $42 \%$ of girls in the study had ever heard about contraception/family planning (Table 5). In addition, knowledge of specific methods is higher among older boys and girls; condoms, pills and injections were the most commonly known methods. Teachers were cited most frequently as the source of information on contraception ( $27 \%$ of boys and $30 \%$ of girls). However, there appears to be a drop in knowledge of the pill and injection in the 2010 survey compared to the 2004 survey, although it was still higher than the 1999 levels. The drop could be attributed to low promotion of contraceptive pills and the injection to adolescents. 
Table 5: Proportions reporting ever heard of specific methods

\begin{tabular}{|c|c|c|c|c|c|}
\hline & $\begin{array}{c}1999 \\
\text { Baseline }\end{array}$ & $\begin{array}{c}2004 \\
\text { Endline }\end{array}$ & $\begin{array}{c}2010 \\
\text { assessment }\end{array}$ & $\begin{array}{c}1999 \text { vs } \\
2010\end{array}$ & $\begin{array}{c}2004 \text { vs } \\
2010\end{array}$ \\
\hline Boys 10-14 & $N=345$ & $N=193$ & $N=154$ & & \\
\hline Condom & $62 \%$ & $87 \%$ & $96 \%$ & $* *$ & $* *$ \\
\hline Pill & $33 \%$ & $74 \%$ & $54 \%$ & $* *$ & $* *$ \\
\hline Injection & $29 \%$ & $71 \%$ & $43 \%$ & $* *$ & $* *$ \\
\hline Boys 15-19 & $\mathrm{N}=\mathbf{2 6 5}$ & $N=248$ & $N=376$ & & \\
\hline Condom & $91 \%$ & $98 \%$ & $100 \%$ & $* *$ & $* *$ \\
\hline Pill & $67 \%$ & $88 \%$ & $85 \%$ & $* *$ & ns \\
\hline Injection & $65 \%$ & $87 \%$ & $73 \%$ & $* *$ & $* *$ \\
\hline Girls 10-14 & $\mathrm{N}=807$ & $N=468$ & $\mathrm{~N}=122$ & & \\
\hline Condom & $47 \%$ & $86 \%$ & $97 \%$ & $* *$ & $* *$ \\
\hline Pill & $26 \%$ & $83 \%$ & $69 \%$ & $* *$ & $* *$ \\
\hline Injection & $28 \%$ & $80 \%$ & $58 \%$ & $* *$ & $* *$ \\
\hline Girls 15-19 & $\mathrm{N}=755$ & $\mathrm{~N}=716$ & $N=429$ & & \\
\hline Condom & $85 \%$ & $94 \%$ & $100 \%$ & $* *$ & $* *$ \\
\hline Pill & $75 \%$ & $93 \%$ & $87 \%$ & $* *$ & $* *$ \\
\hline Injection & $75 \%$ & $92 \%$ & $84 \%$ & $* *$ & $* *$ \\
\hline
\end{tabular}

${ }^{*} \mathrm{P}<0.05 ;{ }^{* *} \mathrm{p}<0.01 ;{ }^{*} \mathrm{~ns}-$ Not statistically significant

Approval for contraceptive use by married adolescents was found to be high (over $66 \%$ from both boys and girls) and much higher for other married couples (over $70 \%$ ). Although most adolescents in the 2010 survey (70\% females and 80\% males) approved condom use for dual protection (against STIs and pregnancy) by sexuallyactive peers, only 31\% approved use of other contraceptive methods by unmarried adolescents.

Knowledge of correct condom use: Respondents in the ten-year evaluation survey were asked to list, the key steps in correctly using a condom, and the results compared to those of the 2004 survey. In both surveys, adolescents' knowledge of correct condom use was low, perhaps due to the weak promotion of condom use in ASRH activities. About $41 \%$ of males and $64 \%$ of females in the study could not identify any step in correct condom use, levels similar to the 2004 survey. These findings seem to suggest that there has been no change in condom use promotion efforts for adolescents aged 10-19 in the study sites over time.

Knowledge of sexually transmitted infections: HIV/AIDS awareness is near universal in 2010 KARHP assessment. Additionally, most adolescents (63\% for both boys and girls) in the study have ever heard of sexually transmitted infections. The majority have heard about STIs from teachers (73\% for boys and $78 \%$ for girls). Nearly half of those who knew any signs of STIs $(48 \%(n=29)$ of females and $48 \%(n=37)$ of males) had experienced symptoms in the last twelve months preceding the survey. Over half of the girls who reported experiencing any signs had sought treatment. Among the boys, $38 \%(n=15)$ of those reported experiencing any signs of STIs sought treatment. Most of the males who did not seek treatment thought it was normal $(47 \% \mathrm{n}=8)$. Among the girls, nearly half of those who did not seek treatment feared being stigmatized at health facilities. Treatment for partners was reportedly very low at $13 \%$ for males and $14 \%$ for females. About $33 \%$ of males and $36 \%$ of females reported ever thinking of getting an HIV test. Among these, 38\% of males and 51\% of girls actually had been tested. Generally, girls in the study reported to seek health services more than boys. 


\section{Effect on adolescents' sexual and related reproductive health behaviors}

Occurrence of sexual activity: The evaluation examined whether occurrence of sexual activity among the adolescents had changed over time. The findings show an increase in the proportions of those reporting delayed initiation of sexual activity of any kind. In the 2004 and 2010 surveys, older adolescents were more likely to have experienced any type of sexual activity than younger adolescents. For instance the 2010 data shows that $7 \%$ of females and $26 \%$ of males had penetrative sex by 10 years of age, compared to $13 \%$ in 2004 . There were no significant changes in the median ages at sexual initiation between the two surveys - the median age in 2004 survey was 14.3 years for boys and 15.2 for girls, comparable with 14 years for boys and 15 years for girls in the 2010 survey. Most sexual encounters among young people were with partners known to them, with no change between the 2004 and 2010 surveys.

Use of condoms and contraception: Consistent condom use is important to reduce risk of sexually transmitted infections; condom use at first sex is an indicator of reduced risk of exposure at the beginning of sexual activity. Young adults who use condoms at first sex are more likely to sustain use later in life. In the 2008/2009 KDHS, only one in four young Kenyans ( $24 \%$ of famales and $26 \%$ of males) reported that they had used a condom the first time they had sex; $42 \%$ of females and $55 \%$ of males reported condom use at last sex (KNBS and ICF Macro. 2010). There is no change in type and source of contraceptive methods used by the majority of adolescents at first and last sex over time between the two surveys. The majority of adolescents who reported use of any method at first and last sex, used condoms with the majority obtaining them from a kiosk (local shop).

The KARHP endline survey in 2004 found that girls were more likely to use condoms than boys at the first sexual intercourse, although this was not the same at the last sexual encounter. The 2010 evaluation findings found similar trends: among the sexually-active adolescents, over half of the girls (53\%) and $34 \%$ of the boys said that they had practiced safe sex the first time they had sexual intercourse. This is an increase from the findings of the 2004 survey where only $19 \%$ of boys and $25 \%$ of girls reported safe sex the first time. The incidence of safe sex at the last intercourse in the 2010 survey increased to $43 \%$ among boys but dropped to $40 \%$ among girls, slight improvements from the findings of the 2004 survey.

Adolescents experience with adverse sexual activity outcomes: This study found an increase in the proportion of girls reporting having been pregnant. Among the sexually-active girls in the sample, $40 \%(n=60)$ had ever been pregnant, which is similar to the findings of the 2004 study. Among sexually-active 10-19 year olds in the 2010 survey, $30 \%$ of girls and $35 \%$ of boys had ever had symptoms of sexually transmitted infections; of these, $48 \%$ had experienced such symptoms in the 12 months preceding the survey. About $41 \%$ of girls and $38 \%$ of boys sought treatment at health facilities. Most of the males who did not seek treatment thought the 
symptoms were normal while females reportedly lacked money to seek treatment; some cited lack of time and fear of stigma as well. 14\% of partners of those who were infected were treated, with female partners being more likely to have gone for treatment.

Table 6: Summary of survey findings on selected indicators over the three KARHP evaluation studies

\begin{tabular}{|c|c|c|c|c|c|}
\hline & 1999 & 2004 & 2010 & $\begin{array}{c}1999 \text { vs } \\
2010\end{array}$ & $\begin{array}{c}2004 \text { vs } \\
2010\end{array}$ \\
\hline \multicolumn{6}{|l|}{ Sexual activity } \\
\hline Boys 10-14 & $N=352$ & $N=387$ & $N=598$ & & \\
\hline Penetrative sex & $13 \%$ & $13 \%$ & $7 \%$ & $* *$ & $* *$ \\
\hline No sexual activity & $80 \%$ & $81 \%$ & $88 \%$ & $* *$ & $* *$ \\
\hline Boys 15-19 & $N=269$ & $\mathrm{~N}=317$ & $N=501$ & & \\
\hline Penetrative sex & $52 \%$ & $51 \%$ & $38 \%$ & $* *$ & $* *$ \\
\hline No sexual activity & $45 \%$ & $43 \%$ & $52 \%$ & ns & $*$ \\
\hline Girls 10-14 & $N=868$ & $N=939$ & $N=678$ & & \\
\hline Penetrative sex & $3 \%$ & $3 \%$ & $2 \%$ & ns & ns \\
\hline No sexual activity & $90 \%$ & $94 \%$ & $96 \%$ & $* *$ & ns \\
\hline Girls 15-19 & $\mathrm{N}=801$ & $\mathrm{~N}=874$ & $\mathrm{~N}=629$ & & \\
\hline Penetrative sex & $30 \%$ & $37 \%$ & $22 \%$ & $* *$ & $* *$ \\
\hline No sexual activity & $64 \%$ & $61 \%$ & $66 \%$ & ns & $*$ \\
\hline \multicolumn{6}{|c|}{ Median age at first sexual encounter } \\
\hline Boys 10-19 & 13.9yrs & 14.3yrs & $14 y r s$ & & \\
\hline Girls 10-19 & $14.8 y r s$ & $15.2 y r s$ & $15 y r s$ & & \\
\hline \multicolumn{6}{|c|}{ Condom use at first and last sexual } \\
\hline Total boys & $\mathrm{N}=185$ & $N=226$ & $N=227$ & & \\
\hline At first intercourse & $18 \%$ & $19 \%$ & $34 \%$ & $* *$ & $* *$ \\
\hline At last intercourse & $34 \%$ & $32 \%$ & $43 \%$ & ns & $* *$ \\
\hline Total girls & $\mathrm{N}=303$ & $N=390$ & $\mathrm{~N}=152$ & & \\
\hline At first intercourse & $21 \%$ & $25 \%$ & $53 \%$ & $* *$ & $* *$ \\
\hline At last intercourse & $24 \%$ & $32 \%$ & $40 \%$ & $* *$ & ns \\
\hline \multicolumn{6}{|c|}{$\begin{array}{l}\text { Ever heard of STIs or HIV/AIDS knowing } \\
\text { ways of avoiding infection }\end{array}$} \\
\hline Total boys & $N=620$ & $N=704$ & $N=1099$ & & \\
\hline Abstain & $37 \%$ & $54 \%$ & $70 \%$ & $* *$ & $* *$ \\
\hline Use condom & $35 \%$ & $45 \%$ & $39 \%$ & ns & $*$ \\
\hline Be faithful personally & $15 \%$ & $19 \%$ & $7 \%$ & $* *$ & $* *$ \\
\hline Ask partner to be faithful & $16 \%$ & $20 \%$ & $9 \%$ & $* *$ & $* *$ \\
\hline Total girls & $N=1694$ & $N=1813$ & $N=1306$ & & \\
\hline Abstain & $42 \%$ & $60 \%$ & $69 \%$ & $* *$ & $* *$ \\
\hline Use condom & $22 \%$ & $31 \%$ & $28 \%$ & $* *$ & ns \\
\hline Be faithful personally & $12 \%$ & $18 \%$ & $9 \%$ & $* *$ & $* *$ \\
\hline Ask partner to be faithful & $17 \%$ & $17 \%$ & $8 \%$ & $* *$ & $* *$ \\
\hline
\end{tabular}

${ }^{*} P<0.05 ;{ }^{* *} p<0.01 ; n s-$ Not statistically significant 


\section{Discussion and conclusion}

Sarriot ${ }^{11}$ defines sustainability as a combination of processes and outcomes to which programs contribute. This involves creating an enabling environment to allow individuals, communities and local organizations to express their potential, improve functionality and decrease dependency on insecure resources - finances, human, technical, informational. As a result, stakeholders are able to negotiate their respective roles in the pursuit of health and development beyond a project intervention.

Study findings show that ASRH activities have been sustained within the public sector. In the past ten years, government ministries have ensured the creation of a policy and legislative environment supportive to meet the SRH/HIV/AIDS needs of young people in Kenya. With support from stakeholders, appropriate ASRH policies and strategic documents have been formulated that recognize, prioritize and increase visibility around ASRH activities. The documents also clearly outline sectoral objectives and define principles to guide national programming. They are strong on identifying gaps and needs, diversity among adolescents, activities to be implemented and strategies for implementation. There have also been deliberate efforts by the three ministries to provide leadership ASRH activity roll-out.

It is clear from the findings that the different ministries have made efforts to allocate funds to support ASRH activities and to build their capacities to implement them. Ministries have adopted a multi-sectoral approach, working with partners in the private sector, donors and NGOs to leverage funding for activities. Other efforts have seen the creation of a new ministry (MOYAS) and departments (Division of Child and Adolescent Health), as well as strengthening existing departments (Guidance and Counseling) to improve focus on addressing the need of young people.

The survey shows that knowledge about reproductive health among young people has improved, and has been sustained since the 2004 evaluation. There is significant increase in the proportions of adolescents who are delaying sexual debut. The results also show significant improvement in the proportions of those who reported safer sexual practices at first sex, in comparison with the 2004 evaluation. Although condoms remain the method of choice for sexually active 10-19 year olds, there are concerns over the poor knowledge of how to use them correctly.

Ministry efforts to sustain ASRH activities within the public sector have faced challenges. Funding has been inadequate, perhaps due to the competing national interests, especially in treatment as opposed to preventive campaigns. Monitoring and evaluation components of the various ministries' ASRH activities have also not

\footnotetext{
${ }^{11}$ Sarriot EG, Winch PJ, Ryan LT, Bowie J, et al. 2004 A methodological approach and framework for sustainability assessment in NGO-Implemented primary health care programs. International Journal of Health Planning and Management $19: 23-41$
} 
been given much priority. For instance, successive AOPs have not endeavored to build on gaps of previous implementation efforts. There is need to streamline coordination, especially of the materials used in life-skills education in schools and their distribution, to avoid the current situation where different manuals and curricula are in use.

It is clear from this study that ASRH activities have received recognition by the government and efforts have been made by the ministries to institutionalize them and assure their sustainability. The KARHP model has been sustained because government ministries have been involved in its design, pilot-testing and scaling up. Activities were also implemented within existing government structures. It can be concluded therefore that with initial support, government ministries can implement and scale up reproductive health and HIV services within the public sector and have sustained effect on adolescent behaviors. However, the government needs to streamline coordination, strengthen funding, and provide effective monitoring and evaluation of its ASRH activities.

Study findings suggest that the implementation of ASRH activities in schools may have an impact on academic performance. This relationship should be investigated in future research. Studies are also needed to examine sustainability of ASRH activities at facilities and at the community levels. 


\section{Annex 1: Policy documents and work plans reviewed}

1. (2004) Education Sector Policy on HIV

2. (2005) Sessional Paper No 1 - Education

3. (2005) Kenya Education Sector Support Programme 2005- 2010

4. (2007) Gender Policy in Education

5. (2009) MOE HIV/AIDS Life-skills Training Manual

6. (2007) National Plan of Action for the Health Component of the National Youth Policy

7. (2008) Ministry of Youth Affairs National policy for youth training

8. (2008-2009) MOYA Directors Work-plan

9. (2009-2010) MOYA Department of Youth Training Workplan

10. Provincial Director of Youth Affairs work-plan, Central

11. (2009) MOYA \&S Performance Contract

12. (2009) MOYA Training Manual - Trainees Handbook

13. (1999) NASCOP Strategic Plan

14. (2003) Kenya Adolescents Reproductive Health and Development policy

15. (2004) RH Research Agenda ${ }^{12}$

16. (2005) Kenya Adolescents Reproductive Health and Development Policy Plan of Action

17. (2006) Community Strategy for delivery of level 1 services

18. (2006) $)^{13} \mathrm{MOH}$ Annual Operational Plan No. 2

19. (2006) $\mathrm{MoH}$ National $\mathrm{RH}$ Curriculum for Service Providers

20. (2007) $\mathrm{MOH}$ Annual Operational Plan No. 3

21. (2007) Reproductive Health Policy (MOH)

22. (2008) DRH Annual Operational Plan No. 4

23. (2009) Kenya National AIDS Strategic Plan

24. (2009) DRH Annual Operational Plan No. 5

25. (2009) FP Guidelines

26. (2008) APHIA II Nyanza IR2 Work plan

27. (2008) APHIA II RV SBC Work-plan

28. (2008) APHIA II Coast SBC plan

29. (2009) APHIA II Nyanza Implementation Strategy review

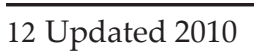

13 ASRH is included in the Kenya Essential Health Package under Cohort 4 (Adolescence) 


\section{Annex 2: Desk review checklist}

From Pilot to Program: Assessing the Status and Sustainability of the Kenya Adolescent Reproductive Health Program 2009

Type of document

Year valid (for annual work plans)

Level/title of document:

National document

Provincial document

District document

\begin{tabular}{|l|l|l|}
\hline & Question/ observation & Comments \\
\hline 1. & $\begin{array}{l}\text { Does the document recognize/ prioritize the need to address adolescent } \\
\text { reproductive health and HIV/AIDS issues? }\end{array}$ & \\
\hline 2. & $\begin{array}{l}\text { Which adolescent reproductive health and HIV/AIDS issues/gaps have } \\
\text { been prioritized? }\end{array}$ & \\
\hline 3 & $\begin{array}{l}\text { To what extend have these issues been prioritized (what groups of } \\
\text { adolescents have been targeted, by who, coverage) }\end{array}$ & \\
\hline 4. & $\begin{array}{l}\text { Is the way the issues highlighted show a clear understanding of ASRH } \\
\text { concerns to be addressed }\end{array}$ & \\
\hline 5. & At what levels are the issues being addressed? & \\
\hline 6. & What strategies/ approaches are used in addressing the prioritized needs & \\
\hline 7. & $\begin{array}{l}\text { What resources have been made a viable for implementation of the said } \\
\text { strategies (human/ financial/ material)? Who is providing? }\end{array}$ & \\
\hline 8. & $\begin{array}{l}\text { Is there a monitoring component to assess the strategies? Who is } \\
\text { responsible for monitoring }\end{array}$ & \\
\hline 9. & What are the identified outcomes? & \\
\hline 10. & What are the achievements & \\
\hline 11. & What are the challenges? & \\
\hline 12. & What are the lessons learnt? & \\
\hline
\end{tabular}


For more information, contact:

Project Director

APHIA II OR Project in Kenya

Population Council

General Accident Insurance House

Ralph Bunche Road

P.O. Box 1764300500

Nairobi, Kenya

Tel: 254202713480 - 3

Fax: 254202713479

www.popcouncil.org/projects/239_APHIAII.asp

\section{(P Population Council}

